\title{
Temporal and spatial differences in the feeding ecology of the Spanish Imperial Eagle Aquila adalberti during the non-breeding season: effects of the rabbit population crash
}

\author{
Roberto SÁNCHEZ ${ }^{1}$, Antoni MARGALIDA ${ }^{2 *}$, Luis Mariano GONZÁlEZ ${ }^{3}$ \& Javier ORIA ${ }^{4}$ \\ ${ }^{1}$ Tragsega-Vida Silvestre, c/ Julián Camarillo 6, E-28037, Madrid, SPAIN \\ $2^{2 *}$ Bearded Vulture Study and Protection Group, Apdo. 43, E-25520 El Pont de Suert, Lleida, SPAIN \\ ${ }^{3}$ Dirección General de Medio Natural y Política Forestal, Ministerio de Medio Ambiente, y Medio Rural y Marino, c/ Ríos \\ Rosas 24 Madrid 28003, SPAIN \\ ${ }^{4} \mathrm{c} /$ San Agustín 22, E-40001, Segovia, SPAIN \\ *Corresponding author, e-mail: margalida@inf.entorno.es
}

\begin{abstract}
Sánchez R., Margalida A., González L. M., Oria J. 2009. Temporal and spatial differences in the feeding ecology of the Spanish Imperial Eagle Aquila adalberti during the non-breeding season: effects of the rabbit population crash. Acta
\end{abstract} Ornithol. 44: 53-58. DOI 10.3161/000164509X464885

\begin{abstract}
The paper describes the diet of territorial Spanish Imperial Eagles during the non-breeding season, comparing prey identified across different regions (Central, Western and Southern), breeding season vs non-breeding season, and periods (1983-1985 or pre-viral haemorrhagic disease [RHD] vs 1991-2000 or post-RHD). Comparison of the nonbreeding with the breeding season revealed a slight variation in the diet. The Rabbit Oryctolagus cuniculus continues to be the most important prey species in the eagle's diet during the non-breeding season, followed by pigeons and the Red Partridge Alectoris rufa, although this varies from one region to another. In general, the decrease in the rabbit population after the epizooty (RHD) does not appear to have had an impact on the occurrence of this prey species in the Spanish Imperial Eagle's diet. Although this species is generally considered to be specialised in the capture of rabbits, the variability found between regions suggests that when the main prey (wild Rabbit) is scarce, the Spanish Imperial Eagle's diet is based on alternative prey such as pigeons or carrion.
\end{abstract}

Key words: Spanish Imperial Eagle, Aquila adalberti, feeding ecology, non-breeding season, rabbit viral haemorrhagic disease, alternative prey

Received — July 2008, accepted - April 2009

\section{INTRODUCTION}

Feeding ecology studies on raptors have mainly focused on describing the diet during the breeding season. This is due to the fact that at this time the presence of raptors is linked to nesting-sites, which makes it easier to observe them and to collect pellets and the remains of prey consumed (Marti 1987). Although these studies are clearly important for the management and application of conservation measures, an incomplete picture of the feeding ecology emerges if we take into account the fact that there are very few specific studies of the diet during the nonbreeding season in the literature (e.g., Watson et al. 1992, 1993, Moleón et al. 2007, Żmihorski \& Rejt 2007). This is particularly important if we bear in mind that winter and climatic conditions can have an impact on the individual survival and body condition, affecting their breeding performance for the subsequent breeding season (e.g., Barbraud \& Weimerskirch 2003, Grosbois \& Thompson 2005).

The Spanish Imperial Eagle is a species that is considered Vulnerable (IUCN 2007), with an increasing population estimated at around 200 breeding pairs (González et al. 2008). The Spanish Imperial Eagle's diet has only been studied partially in a few locations during the breeding season (Valverde 1967, Garzón 1973, Delibes 1978, Veiga et al. 1984, González 1991). From the information published it emerges that this species' diet is based on the wild Rabbit Oryctolagus cuniculus (see Sánchez et al. 2008). However, aspects of the eagle feeding ecology during the non-breeding season remain practically unknown. In this respect, only descriptive and not analysed data have been provided by González (1991). 
The species is found in the south-western quarter of the Iberian Peninsula, where it is split into five subpopulations: Northern, Central, Western, Southern and Doñana (for more details see González et al. 2006a,b, Ortega et al. 2009). Most of the breeding pairs inhabit plains and mountains with patches of Mediterranean woodland, and open pastures with holm and evergreen cork oaks (González et al. 1992).

In 1989, the rabbit population in the Spanish Imperial Eagle range was affected by an epizooty (viral haemorrhagic disease, RHD) (Argüello et al. 1988, Villafuerte et al. 1994). RHD had a huge impact on rabbit populations, reducing their original range by between a half and two thirds in only five years (1988-1993), and even led to local extinctions in areas with low rabbit density (Blanco \& Villafuerte 1993, Villafuerte et al. 1994, 1995). Thus, after the decrease in the number of rabbits, which constituted the Spanish Imperial Eagle's most important prey, the eagle feeding habits may have changed, adapting to the consumption of alternative prey species.

In this study we took advantage of dietary data obtained during the non-breeding seasons in the pre-RHD period (1983-1985) in the same study area (González 1991) in order to evaluate whether the Spanish Imperial Eagle's diet changed during the post-RHD period (1991-2000). Our goals were to analyse the diet of territorial Spanish Imperial Eagles during the non-breeding season in order to 1) compare the diet during the non-breeding and breeding season, 2) to document whether temporal changes occurred as a consequence of the rabbit crash, comparing data obtained before and after RHD.

\section{STUDY AREA AND METHODS}

In its current range, the highest densities of Spanish Imperial Eagle are found on the plains and in the mountainous regions with Mediterranean woodland, and on the open pastures with holm and evergreen cork oaks, where the European rabbit is common (González et al. 1992). The altitude of this area ranges between 350-2460 m a.s.l., with a cold continental Mediterranean climate.

The study was carried out in 24 territories, in three subregions of the Spanish Imperial Eagle distribution, known as the Central $(\mathrm{n}=10)$, Western $(\mathrm{n}=11)$ and Southern subregions $(\mathrm{n}=3)$ (Fig. 1). Pellets $(n=312)$ were collected between

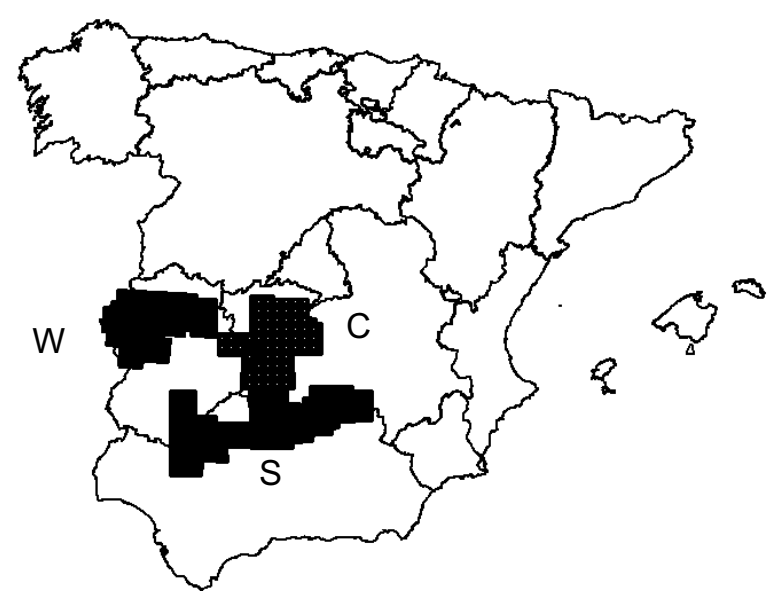

Fig. 1. Subpopulations of the Spanish Imperial Eagle's studied: W - Western, C - Central, S - Southern.

1991-2000 (after the rabbit crash) from OctoberFebruary at resting places, coinciding with the end of the juveniles' dependence period up to egg-laying (see González 1991, Margalida et al. 2007). Although this indirect method overestimated birds and underestimated mammals, in the case of the Spanish Imperial Eagle, the pellet analysis seems to be a method closest to the direct observation (Sánchez et al. 2008). In addition, pellets were the only source of information that could be reliably obtained in both periods (breeding and non-breeding season, see Watson et al. 1993).

Prey species identified were split into seven categories: rabbits, pigeons (including Columba palumbus and Columba spp.), Red-legged Partridge Alectoris rufa, other birds (mainly corvids and other bird species), carrion (principally remains of Sheep Ovis aries, Red Deer Cervus elaphus, and Cow Bos taurus), reptiles and other mammals (including the Brown Hare Lepus europaeus and the Red Fox Vulpes vulpes). To assess the importance of the prey biomass, the mass of prey was estimated following González (1991) taking into account the weight of the prey ingested during a trophic test carried out with two captive Spanish Imperial Eagles. The biomass of prey categories was: rabbit $332.1 \mathrm{~g}$, pigeons $220 \mathrm{~g}$, partridge $310 \mathrm{~g}$, other birds $140 \mathrm{~g}$, carrion $375 \mathrm{~g}$, reptiles $230 \mathrm{~g}$ and other mammals $332.1 \mathrm{~g}$ (González 1991).

By regions, 146 prey items were obtained from the Central region ( $\mathrm{n}=104$ pellets), 169 from the Western ( $\mathrm{n}=121$ pellets) and 124 from the Southern ( $\mathrm{n}=87$ pellets). We compared prey 
identified across the different regions (Central, Western and Southern), seasons (breeding season vs non-breeding season) and periods (1983-1985 or pre-RHD vs $1991-2000$ or post-RHD). For the comparison of seasons we used data obtained from four focal pairs during post-RHD period (inhabiting in Central and Western region) in which data were available for both periods (breeding, $\mathrm{n}=239$ pellets and non-breeding season, $\mathrm{n}=$ 312 pellets). To analyse changes in the diet between periods (pre-RHD vs post-RHD), we compared the food habits of six pairs known in the period 1983-1985 (pre-RHD, $\mathrm{n}=180$ pellets) with the pairs inhabiting the same study area (Central and Western, $\mathrm{n}=21$ ) in 1991-2000 (postRHD).

Comparisons of prey categories were performed by means of chi-square analyses on contingency tables (Zar 1996).

\section{RESULTS}

\section{Dietary differences by regions}

During the non-breeding season (OctoberFebruary), we identified a total of 439 prey items. The main prey in the three regions (Table 1) was the wild rabbit, followed by pigeons in the Central and Western regions and partridge in the Southern, and other birds in the Central and the Western, and pigeons in the Southern region. The other prey categories were of minor importance. When we analysed the diet composition across regions (excluding the reptiles category) we found significant differences $\left(\chi^{2}=84.95, \mathrm{df}=10, \mathrm{p}<0.0001\right.$; Table 1$)$. The differences were found in the rabbit category, with a significantly lower presence in the Western region than expected $\left(\chi^{2}=25.80, \mathrm{df}=2, \mathrm{p}<\right.$ $0.0001)$ whereas pigeons had a higher presence $\left(\chi^{2}=19.73, \mathrm{df}=2, \mathrm{p}<0.0001\right)$. In the Southern region, partridge was the predominant category $\left(\chi^{2}=34.32, \mathrm{df}=2, \mathrm{p}=0.0001\right)$ being other birds less abundant than expected $\left(\chi^{2}=12.24, \mathrm{df}=2\right.$, $p=0.002)$ whereas in the Central region carrion was absent $\left(\chi^{2}=10.28, \mathrm{df}=2, \mathrm{p}=0.006\right)$. When we compared the frequency of prey by weight categories (Table 1) the results were similar. The rabbit continued to be the most important prey item in all regions, followed by pigeons in the Central and Western regions, and partridge in the Southern. Only the third most important prey category varied in two regions (Central and Western) in relation to the percentage of occurrence (the other birds category in both regions), with the other mammals category in the Central region and carrion in the Western being the third category that provided most biomass.

\section{Dietary differences by seasons}

We found differences between the diet during the non-breeding and the breeding season in four focal territories during the same study period (Fig. 2 ). The proportion of pigeons and other birds was significantly higher during the breeding season, whereas the proportion of partridge and carrion predominated during winter.

\section{Effects of the rabbit haemorrhagic disease}

When we compared the diet between the two study periods (pre-RHD vs post-RHD), the results showed significant differences (Table 2). Although in both periods rabbit constituted the most important prey species, during the pre-RHD period (1983-1985) the frequency of pigeons was significantly lower and the other birds and other mammals categories significantly higher in comparison with data obtained during the post-RHD period (1991-2000).

Table 1. Percentage of occurrence and biomass of different prey items found in Spanish Imperial Eagle pellets during the non-breeding season (post- RHD period 1991-2000) in three subpopulations. N - total number of prey items.

\begin{tabular}{lccrrrr}
\hline & \multicolumn{2}{c}{$\begin{array}{c}\text { Central } \\
(\mathrm{N}=146)\end{array}$} & \multicolumn{2}{c}{$\begin{array}{c}\text { Western } \\
(\mathrm{N}=169)\end{array}$} & \multicolumn{2}{c}{$\begin{array}{c}\text { Southern } \\
(\mathrm{N}=124)\end{array}$} \\
& Occurrence & Biomass & Occurrence & Biomass & Occurrence & Biomass \\
\hline Rabbits & 75.4 & 82.2 & 47.9 & 56.5 & 65.3 & 67.2 \\
Pigeons & 11.6 & 8.4 & 24.3 & 18.9 & 6.5 & 4.4 \\
Partridges & 0.7 & 0.7 & 4.7 & 5.2 & 18.5 & 17.8 \\
Other birds & 7.5 & 3.5 & 12.4 & 6.2 & 0.0 & 0.0 \\
Carrion & 0.0 & 0.0 & 7.1 & 9.4 & 4.85 & 5.6 \\
Reptiles & 0.0 & 0.0 & 1.2 & 1.0 & 0.0 & 0.0 \\
Other mammals & 4.8 & 5.2 & 2.4 & 2.8 & 4.85 & 5.0 \\
\hline
\end{tabular}




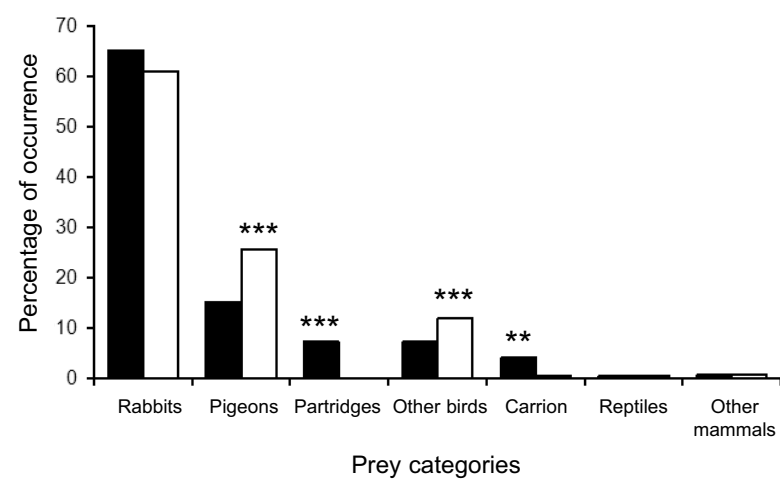

Fig. 2. Percentage of the occurrence of prey in the Spanish Imperial Eagle's focal pairs during the non-breeding and breeding seasons (post-RHD). Black bars: non-breeding; white bars: breeding season. Statistical differences are indicated by asterisks: ${ }^{*}-\mathrm{p}<0.05,{ }^{* *}-\mathrm{p}<0.01,{ }^{* * *}-\mathrm{p}<0.001$.

\section{DISCUSSION}

The results show a slight variation in the Spanish Imperial Eagle diet comparing the nonbreeding and breeding seasons. The rabbit continues to be the most important prey item in the eagle's diet during the non-breeding season (average of the three subpopulations: 63\%), followed by pigeons and partridge. However, during the non-breeding season the occurrence of pigeons and other birds increased. This could be explained by the greater abundance of the Woodpigeon in winter, a species whose presence has increased notably in the Spanish Imperial Eagle range over the last few decades (Martí \& del Moral 2003). In addition, during the non-breeding season partridges were observed more frequently (Southern region) as was carrion (Western region). This was probably due to a greater availability of partridges

Table 2. Differences in the percentage of prey occurrence during the non-breeding season between the 1991-2000 (postRHD) and 1983-1985 (pre-RHD) periods in the CentralWestern population. $\mathrm{N}-$ total number of prey items. Significance levels: ${ }^{*}-\mathrm{p}<0.05,{ }^{* * *}-\mathrm{p}<0.001$.

\begin{tabular}{lcc}
\hline & $\begin{array}{c}\text { Pre-RHD } \\
(\mathrm{N}=270) \\
\text { (González 1991) }\end{array}$ & $\begin{array}{c}\text { Post-RHD } \\
(\mathrm{N}=315) \\
\text { (this study) }\end{array}$ \\
\hline Rabbits & 53.0 & 60.6 \\
Pigeons & 12.2 & $18.4^{*}$ \\
Partridges & 0.7 & 2.9 \\
Other birds & 16.7 & $10.12^{*}$ \\
Carrion & 3.0 & 3.8 \\
Reptiles & 2.2 & 0.6 \\
Other mammals & 12.2 & $3.5^{\text {*** }}$ \\
\hline
\end{tabular}

at this time, as a result of the release of individuals bred on farms (authors' unpubl. data.). For example, in the Southern region the importance of the partridge is notable, due to the fact that the pairs studied are located in a region (Campo de Montiel) that is very rich in small game species such as the Red-legged Partridge. Moreover, the higher frequency of carrion in the Central region was probably a result of the greater availability of carrion proceeding from big game hunting. The remains of these animals probably provided a significant alternative source of prey that constituted 7\% of the Spanish Imperial Eagle's diet.

In other regions such as the Doñana subpopulation, dietary differences between the breeding and non-breeding periods may be greater as a result of some individuals becoming specialised in hunting the Greylag Goose Anser anser in winter (González 1991). This suggests that, although the Spanish Imperial Eagle can be considered as a true trophic specialist, it can shift to alternative prey species when populations of their main prey (wild rabbit) are scarce. According to the alternative prey hypothesis (APH, Angelstam et al. 1984) the assemblage of a generalist predator such as the Spanish Imperial Eagle may synchronise the fluctuations of their main and alternative prey groups. Although in some regions such as the Western one (this study) or the Doñana region (González 1991), the importance of rabbits is lower and the eagle can shift to alternative prey.

Concerning the dietary shifts between periods, the rabbit crash after RHD does not appear to have changed the Spanish Imperial Eagle's diet substantially. On the one hand, this suggests a high trophic specialisation taking into account that the rabbit is less abundant in winter than in spring-summer, and that its abundance may be influenced by the annual rainfall pattern (Soriguer 1981). On the other hand, these results suggest that, despite the spatial variability and the Spanish Imperial Eagle's adaptation to alternative prey, in the eagle's hunting areas the population of the rabbit as main prey species remains constant.

As a super specialist, the Spanish Imperial Eagle has been considered a species close to extinction as a result of an ecological trap: their extreme and apparently irreversible "adaptation" to a rabbit prey base (Ferrer \& Negro 2004). Although the wild rabbit is in general the most important prey species, our results suggest a certain diet plasticity, at least during the nonbreeding season in some regions such as the 
Western one (this study) or in the Doñana region (González 1991), adapting its diet to other, alternative, more abundant prey species when the rabbit is scarce (Reif et al. 2001). In this respect, in the Spanish Imperial Eagle's diet during the nonbreeding season, carrion and birds (principally pigeons), constitute substitute the rabbit as prey when the latter is not abundant.

\section{ACKNOWLEDGEMENTS}

We would particularly like to thank the official wardens and the Consejerías de Medio Ambiente of the autonomous communities of Extremadura, Castilla la Mancha and Madrid for the information on sightings they kindly provided. This study was funded by the Dirección General para la Biodiversidad del Ministerio de Medio Ambiente.

\section{REFERENCES}

Angelstam P., Lindstrom E., Widen P. 1984. Role of predation in short-term population fluctuations of some birds and mammals in Fennoscandia. Oecologia 62: 199-208.

Argüello J. L., Llanos A., Pérez-Ordoyo L. I. 1988. [The rabbit haemorrhagic disease in Spain]. Med. Vet. 5: 645-650

Barbraud C., Weimerskirch H. 2003. Climate and density shape population dynamics of a marine top predator. Proc. $\mathrm{R}$. Soc. B 270: 2111-2116.

Blanco J. C., Villafuerte R. 1993. [Ecological factors influencing the rabbit populations. Incidence of Haemorrhagic Disease]. TRAGSA-Ministerio de Medio Ambiente, Madrid.

Delibes M. 1978. [Feeding ecology of the Spanish imperial eagle (Aquila adalberti) during the chick-rearing in the Coto of Doñana]. Doñana Acta Vertebr. 5: 35-60.

Ferrer M., Negro J. J. 2004. The near extinction of two European large predators: super specialists pay a prey. Conserv. Biol. 18: 344-349.

Garzón J. 1973. [Contribution to the study of the status, feeding and protection of the Falconiformes in central Spain]. Ardeola 19: 279-330.

González L. M. 1991. [Natural history of the Spanish imperial eagle (Aquila adalberti Brehm, 1861]. Colección Técnica. Instituto para la Conservación de la Naturaleza, Madrid.

González L. M., Bustamante J., Hiraldo F. 1992. Nesting habitat selection of the Spanish imperial eagle (Aquila adalberti). Biol. Conserv. 59: 45-50.

González L. M., Margalida A., Sánchez R., Oria J. 2006a. Supplementary feeding as an effective tool for improving breeding success in the Spanish imperial eagle (Aquila adalberti). Biol. Conserv. 129: 477-486.

González L. M., Oria J., Margalida A., Sánchez R. 2006b. Effective natal dispersal and age of maturity in the threatened Spanish imperial eagle (Aquila adalberti): conservation implications. Bird Study 53: 285-293.

González L. M., Oria J., Sánchez R., Margalida A., Aranda A., Prada L., Caldera J., Molina J. I. 2008. Status and habitat changes in the endangered Spanish Imperial Eagle Aquila adalberti population during 1974-2004: implications for its recovery. Bird Conserv. Int. 18: 242-259.
Grosbois V., Thompson P. M. 2005. North Atlantic climate variation influences survival in adult fulmars. Oikos 109: 273-290.

IUCN 2007. Red List of Threatened Species. IUCN, Gland, Switzerland. www.iucnredlist.org. Downloaded 03.07.2008.

Margalida A., González L. M., Sánchez R., Oria J., Prada L., Caldera J., Aranda A., Molina J. I. 2007. A long-term scale study of the breeding biology of Spanish imperial eagles Aquila adalberti. J. Ornithol. 148: 309-322.

Marti C. D. 1987. Raptor food habit studies. In: Giron Pendleton B. A., Millsap B. A., Cline K. W., Bird D. M. (eds). Raptor Management Techniques Manual, National Wildlife Federation, Washington, pp. 67-80.

Martí R., del Moral J. C. (eds). 2003. [Atlas of the breeding birds of Spain]. Dirección General de Conservación de la Naturaleza-Sociedad Espańola de Ornitología, Madrid.

Moleón M., Gil-Sánchez J. M., Real J., Sánchez-Zapata J. A., Bautista J., Sánchez-Clemot J. F. 2007. Non-breeding feeding ecology of territorial Bonelli's eagles Hieraaetus fasciatus in the Iberian Peninsula. Ardeola 54: 135-143.

Ortega E., Mańosa S., Margalida A., Sánchez R., Oria J., González L. M. 2009. A demographic description of the recovery of the Vulnerable Spanish imperial eagle Aquila adalberti. Oryx 43: 113-121.

Reif V., Tornberg R., Jungell S., Korpimäki E. 2001. Diet variation of common buzzards in Finland supports the alternative prey hypothesis. Ecography 24: 267-274.

Sánchez R., Margalida A., González L. M., Oria J. 2008. Biases in diet sampling methods in the Spanish Imperial Eagle Aquila adalberti. Ornis Fennica 85: 82-89.

Soriguer R. C. 1981. [Ecology and population dynamics of a population of wild rabbits (Oryctolagus cuniculus) in Sierra Morena, Huelva]. Doñana Acta Vertebr. 8: 1-379.

Valverde J. A. 1967. [Structure of a land vertebrate community]. Monografia No 1 Estación Biológica de Donana. CSIC, Sevilla.

Veiga J. P., Alonso J. C., Alonso J. 1984. [On the Spanish imperial eagle Aquila heliaca adalberti population of the Sierra de Guadarrama]. Rapinyaires Mediterranis II: 54-59.

Villafuerte R., Calvete C., Blanco J. C., Lucientes J. 1995. Incidence of viral haemorrhagic disease in wild rabbit populations in Spain. Mammalia 59: 651-659.

Villafuerte R., Calvete C., Gortázar C., Moreno S. 1994. First epizootic of rabbit haemorrhagic disease (RHD) in free living populations of Oryctolagus cuniculus at DNP, SW Spain. J. Wildl. Dis. 30: 176-179.

Watson J., Leitch A. F., Broad R. 1992. The diet of the Sea Eagles Haliaeetus albicilla and Golden Eagles Aquila chrysaetos in western Scotland. Ibis 134: 27-31.

Watson J., Leitch A. F., Rae S. R. 1993. The diet of Golden Eagles Aquila chrysaetos in Scotland. Ibis 135: 387-393.

Zar 1996. Biostatistical Analysis. $3^{\text {rd }}$ ed. Princeton-Hall, New Jersey.

Żmihorski M., Rejt Ł. 2007. Weather-dependent variation in the cold-season diet of urban Kestrels Falco tinnunculus. Acta Ornithol. 42: 107-113.

STRESZCZENIE

[Zróżnicowanie diety orła iberyjskiego w okresie pozalęgowym $\mathrm{w}$ związku z załamaniem się populacji królików].

Dietę terytorialnych orłów iberyjskich opisano $\mathrm{w}$ oparciu o analizę wypluwek. W pracy porównano: udział grup zdobyczy w 3 różnych 
regionach występowania tego gatunku w Hiszpanii (Fig. 1), dietę $w$ okresie lęgowym i pozalęgowym, oraz dietę $w$ dwóch okresach $-\mathrm{z}$ lat 1983-1985, przed epizoocją wirusowego pomoru królików, oraz 1991-2000, po okresie tej choroby, która silnie zredukowała liczbę dzikich królików. Zanotowano dość znacznie różnice pomiędzy badanymi regionami $-\mathrm{w}$ okresie nielęgowym dzikie króliki $\mathrm{w}$ dalszym ciągu stanowiły główną zdobyczą, choć istotną rolę pełniły też gołębie i góropatwy czerwone (Tab. 1). Stwierdzono różnice $\mathrm{w}$ diecie między okresem lęgowym i poza- lęgowym: udział gołębi i innych ptaków był większy w okresie lęgowym, a góropatw i padliny zimą (Fig. 2). Nie stwierdzono, aby spadek liczebności królików po epizoocji odzwierciedlał się zmianą częstości występowania tego gatunku $\mathrm{w}$ diecie orła iberyjskiego (Tab. 2). Mimo, że uznaje się, że orzeł ten jest wyspecjalizowany w łapaniu królików, dość duża zmienność diety pomiędzy regionami sugeruje, że kiedy zdobycz główna jest rzadka, ptaki bazują na zdobyczy alternatywnej (np. gołębie, padlina). 